\title{
DRAINAGE OF THE AUSTRE OKSTINDBREEN ICE-DAMMED LAKE, OKSTINDAN, NORWAY
}

\author{
By N. TVIS KNUDSEN
}

(Geological Institute, University of Aarhus, DK-8000 Arhus C, Denmark)

and WILFRED $\mathrm{H}$. THEAKSTONE

(Department of Geography, University of Manchester, Manchester M13 9PL, England)

ABSTRACT. Observations of the discharge, electrical conductivity, cationic content, and isotopic composition of glacier-river water indicate that drainage of the lake dammed at the margin of the glacier Austre Okstindbreen, Okstindan, Norway, is preceded by disruption of the glacier's drainage system(s). Annual studies over a period of 12 years have demonstrated that intense storm precipitation, changes of ablation conditions, and the stage of development of drainage systems all may play a role in triggering drainage of the ice-dammed lake. Water temperature may influence the course of the outburst. The lake has drained on at least ten occasions in the last 12 years. Three of the events (1979, 1985, and 1986) occurred early in the summer, whilst melting of the winter's snow cover was contributing substantially to glacier-river discharge: high basal water pressure and rapid sliding may have facilitated disruption of drainage conditions within the glacier. In 1982, the lake drained during a severe storm, in 1977 and 1984 shortly after a period of heavy rainfall. During the 1977 and 1984 events, water under pressure burst up through the glacier surface. The lake basin remained partly filled throughout one summer (1980): in-flow of water was balanced by out-flow into the glacier.

\section{INTRODUCTION}

Sudden releases of water previously impounded in glacier-margin lakes, which may have significant local economic consequences, are of both hydrological and glaciological interest. Light may be shed on the causes and evolution of such events by the characteristics of the water which issues from glaciers when ice-dammed lakes drain periodically beneath or through the ice. Although data from several glacier-river floods have been found to fit an empirical relationship between the maximum discharge and the initial lake volume (Clague and Mathews, 1973), explanations of the events ("jökulhlaups") must account for both the initiation of lake drainage and the form of the out-flow hydrograph, which commonly is asymmetrical, a very steep falling limb following a rising limb which itself steepens as discharge increases to the maximum (Liestøl, 1956; Clarke, 1982).

Drainage of water in 1976 and 1977 from a lake dammed at the western margin of the Norwegian glacier Austre Okstindbreen was described by Knudsen (1978) and Theakstone (1978). Although observations of the glacier and lake have continued, it was not until 1984 that water draining from the lake was seen during an outburst. In the intervening period, with a single exception, the lake drained either before or after the period of field work in the area, or the lake did not fill completely during the autumn, spring and winter following drainage, and so did not drain during the summer (Table I). On one occasion (1982), the lake drained during bad weather conditions and the event was only detected during subsequent inspection of the hydrograph and a visit to the lake basin.

\section{LOCATION AND PREVIOUS OBSERVATIONS}

Austre Okstindbreen (lat. $66^{\circ} 00^{\prime}$ N., long. $14^{\circ} 16^{\prime} \mathrm{E}$.) is the largest outlet of the eastern Okstindan ice cap. Its accumulation area covers about $11.4 \mathrm{~km}^{2}$ between 1700 and $1200 \mathrm{~m}$. The ablation area (about $3 \mathrm{~km}^{2}$ ) lies between 1200 and $740 \mathrm{~m}$ (Fig. 1). Between about 1200 and $1000 \mathrm{~m}$, the glacier is heavily broken by crevasses in an ice fall. Since 1908, the glacier has experienced an almost constant, well-documented retreat (Hoel, 1910, 1962; Lewis, 1967; Worsley, 1974; Andreasen and Knudsen, 1985).

The river which issues from Austre Okstindbreen flows eastward through the valley Oksfjelldalen to the lake Grasvatnet (Fig. 1). In most recent summers, this river has

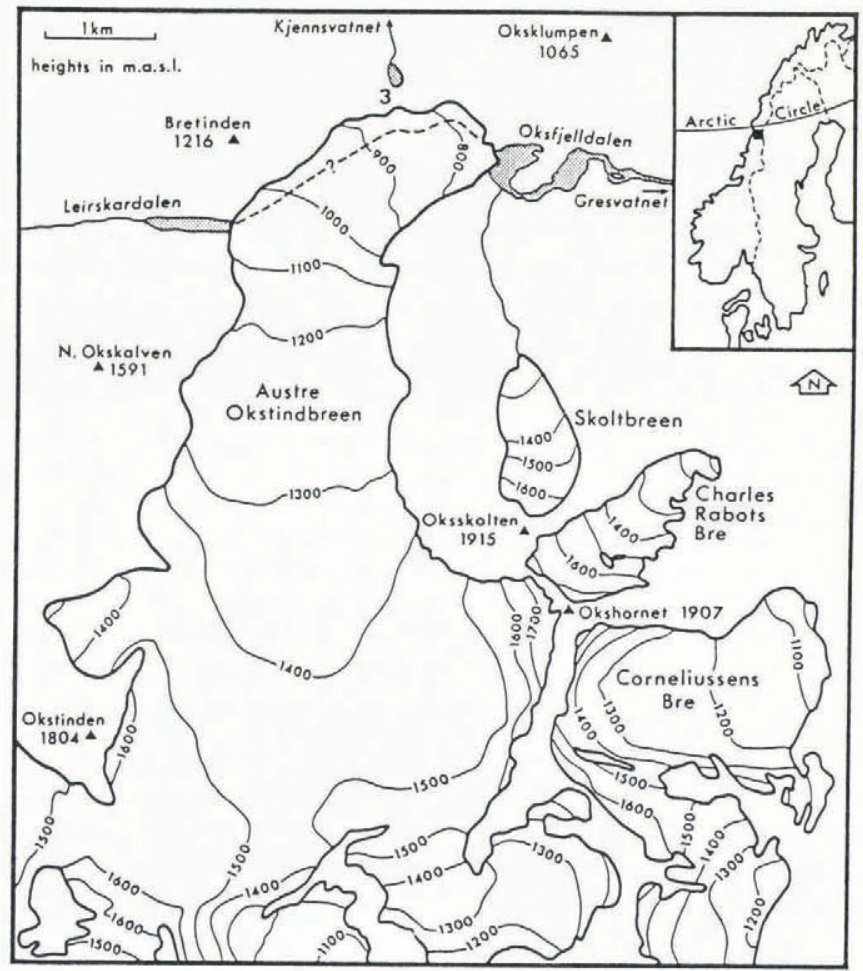

Fig. 1. Austre Okstindbreen and adjacent glaciers, Okstindan, Norway. During drainage of the ice-dammed lake at the head of Leirskardalen, water passes through the glacier. In 1984, water discharging from the lake emerged at the glacier surface due south of site 3 , the outlet to Kjennsvatnet; a possible route is indicated (broken line). A conduit has been observed between this point and site 2 (Fig. 2), where the level and conductivity of the river water leaving the glacier are recorded and water samples are collected for chemical and isotopic analysis. 
TABLE I. GLACIAL LAKE OUTBURSTS, AUSTRE OKSTINDBREEN

\begin{tabular}{|c|c|c|}
\hline Year & $\begin{array}{l}\text { Period of field } \\
\text { observations }\end{array}$ & $\begin{array}{l}\text { Date of lake } \\
\text { drainage }\end{array}$ \\
\hline 1976 & 7 July -25 August & 31 July-1 August \\
\hline 1977 & 8 July -28 August & 5 August \\
\hline 1978 & 5 July-2 August & Mid-August* \\
\hline 1979 & 4 July-4 August & $\begin{array}{l}30 \text { June and late } \\
\text { summer* }\end{array}$ \\
\hline 1980 & 4 July-16 August & $\begin{array}{l}\text { No observed } \\
\text { drainage }\end{array}$ \\
\hline 1981 & 4 July-5 August & $\begin{array}{l}\text { No observed } \\
\text { drainage }\end{array}$ \\
\hline 1982 & 5 July-19 August & 19-20 July \\
\hline 1983 & 7 July-8 August & $\begin{array}{l}\text { No observed } \\
\text { drainage }\end{array}$ \\
\hline 1984 & 5 July -6 August & 29 July \\
\hline 1985 & 5 July-5 August & Early July* \\
\hline \multirow[t]{2}{*}{1986} & 20-24 May & \\
\hline & 5 July -3 August & $\begin{array}{l}\text { Late June- } \\
\text { early July* }\end{array}$ \\
\hline 1987 & 22-25 May & \\
\hline & -2 & \\
\hline
\end{tabular}

14-16 September
Related observations

Drainage eastward to Grasvatnet

Drainage northward to Kjennsvatnet

Drainage northward to Kjennsvatnet

Drainage northward to Kjennsvatnet on both occasions

Basin part full throughout field season; surface-level fluctuating around $1.7 \mathrm{~m}$ below maximum

Basin full throughout field season

Drainage eastward to Grasvatnet (see text for details)

Basin full throughout field season

Drainage eastward to Grasvatnet (see text for details)

Basin empty throughout field season (see Fig. 10)

Basin full (surface not frozen)

Basin empty throughout field season

Basin near empty

Drainage eastward to Grasvatnet; basin did not empty completely

Basin part full; glacier calving

* Exact dates of outbursts which occurred before or after the field season are not known. Observations indicate that the 1985 and 1986 events occurred within a few days of the start of the field season.

discharged into a small pond at about $760 \mathrm{~m}$; below the pond, the water has re-entered the glacier, to appear again at the northern shore of the lake which borders the glacier front (Fig. 2). Water level has been recorded at the outlet of this lake (site 1) every summer since 1976. When possible, recording has also been carried out where water

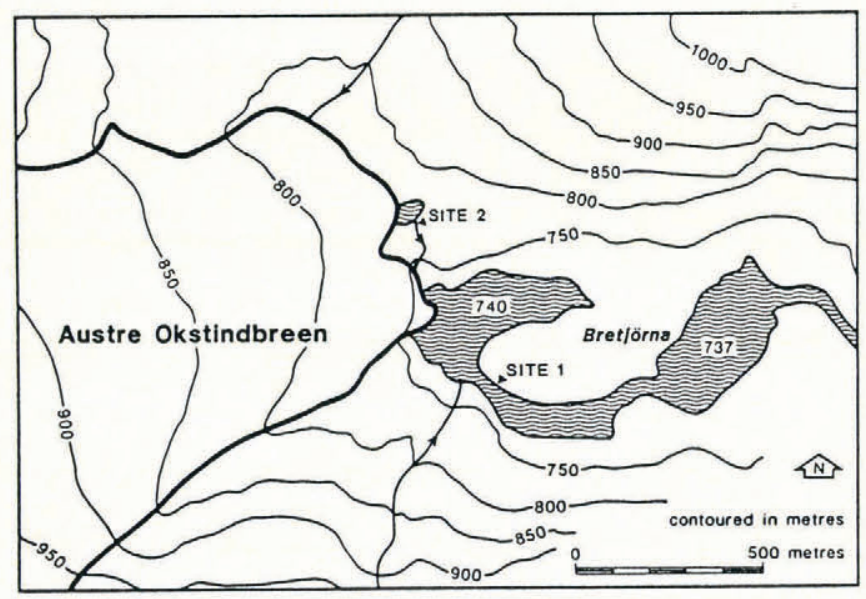

Fig. 2. Location of the site 1 and site 2 water-level recorders. leaves the $760 \mathrm{~m}$ pond (site 2). Usually, the patterns of water-level variation at the two sites are very similar, despite differences in stream velocity and channel crosssection; the water which passes through site 2 later passes through site 1.

Until 1980, a minor stream issued from the glacier's northern outlet at about $830 \mathrm{~m}$ (site 3, Fig. 1); the water passed through a small lake within $100 \mathrm{~m}$ of the margin and flowed to Kjennsvatnet (Theakstone and Knudsen, 1981). In 1980, the glacier margin retreated below the elevation of the local topographic divide, and melt water ceased to issue regularly from the northern side of the glacier. The stream flowing to $\mathrm{K}$ jennsvatnet accommodated almost all the water draining from the ice-dammed lake in the course of the 1977 outburst (Theakstone, 1978), and a small amount followed this route during the maximum discharge associated with the 1984 outburst.

The lake dammed by the western margin of Austre Okstindbreen is in Leirskardalen, the narrow valley between Nordre Okskalven and Bretinden (Fig. 1). When the surface reaches the high-water level at $998 \mathrm{~m}$, water flows westward. In 1965, the surface area of the lake, determined from a 1:5000 scale map plotted from aerial photographs, was about $40000 \mathrm{~m}^{2}$; examination of photographs taken in 1975 and 1976 indicated that almost no change in areal extent had taken place. The volume of water leaving the lake during the 1976 outburst was determined as $3.4 \times 10^{5}$ $\mathrm{m}^{3}$ (Knudsen, 1978). After the lake drains beneath the glacier, some water remains in the western part of the 
basin, behind a threshold $7 \mathrm{~m}$ below the level of the outlet to the west. In several years after the lake had drained, a conduit entrance could be seen beneath the glacier at the lowest part of the basin, where the water had been about $13 \mathrm{~m}$ deep. Subsequently, water entering the basin flowed under the glacier by way of this passage.

\section{THE 1982 DRAINAGE OF THE ICE-DAMMED LAKE}

Between 12.30 and $13.00 \mathrm{~h}$ on 17 July 1982 , ice washed out from beneath the glacier partially blocked the river course at site 2: the level rose by $13 \mathrm{~cm}$ (Fig. 3), and the turbidity of the water increased markedly. The conductivity began to rise, in contrast to the normal pattern, in which daily minima occur in late afternoon (Fig. 4). It appeared that subglacial collapse had disrupted part of the glacier's drainage system. At site 1, there was no unusual change of water level.

Between 17 and 19 July, much "noise", in the form of abrupt water-level changes, was noted at site 2 (Fig. 3). On 18 July, the usual diurnal variation of conductivity did not occur, values continuing to fall through the afternoon (Fig. 4). As discharge rose during the early afternoon of 19 July, conductivity declined sharply until the station was put out of action by the flood at $14.00 \mathrm{~h}$. Conductivity at site 1 also declined through the afternoon of 18 July, but rose sharply during the following morning and fluctuated markedly as discharge increased after noon (Figs 3 and 4). As discharge declined until noon on 20 July, conductivity at site 1 rose, but the secondary peak of discharge during the afternoon was not reflected in the conductivity record: the "normal" diurnal pattern was not resumed until 21 July (Fig. 4). The observations suggested that drainage of the lake on 19-20 July may have been related to the change in the glacier's drainage system on 17 July.

\section{THE 1984 DRAINAGE OF THE ICE-DAMMED LAKE}

In 1984, water level and electrical conductivity were measured at site 2 until the instruments there were destroyed by the flood of 29 July. Water samples were

AUSTRE OKSTINDBREEN 1982

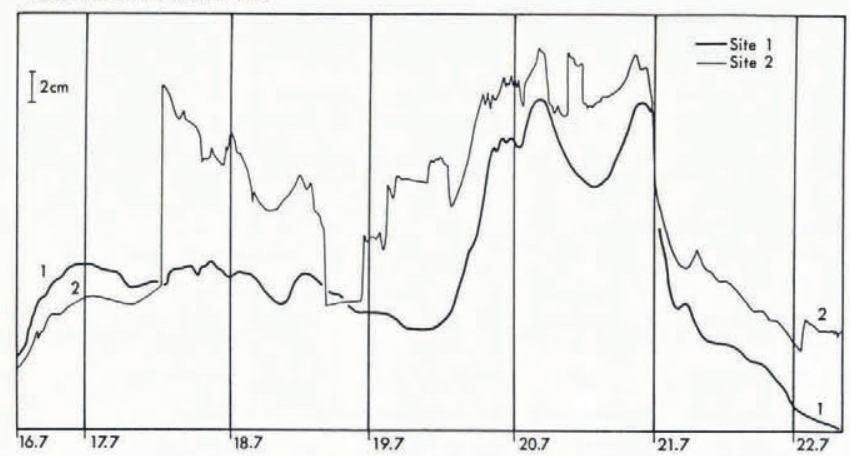

Fig. 3. Glacier river-water level at sites 1 and 2, 16-22 July 1982. Much "noise" in the form of abrupt water-level changes is apparent in the site 2 record. collected at site 2 for analyses of cations $\mathrm{Ca}^{++}, \mathrm{Na}^{+}, \mathrm{K}^{+}$, and $\mathrm{Mg}^{++}$, and of ${ }^{18} \mathrm{O}$ content. Despite precautions, some equipment and data were lost during the outburst. Nevertheless, much information was collected about the event and about the changes that occurred within the glacier's drainage system before, during and after the lake outburst. The observations are summarized in Table II and illustrated in Figure 5 .

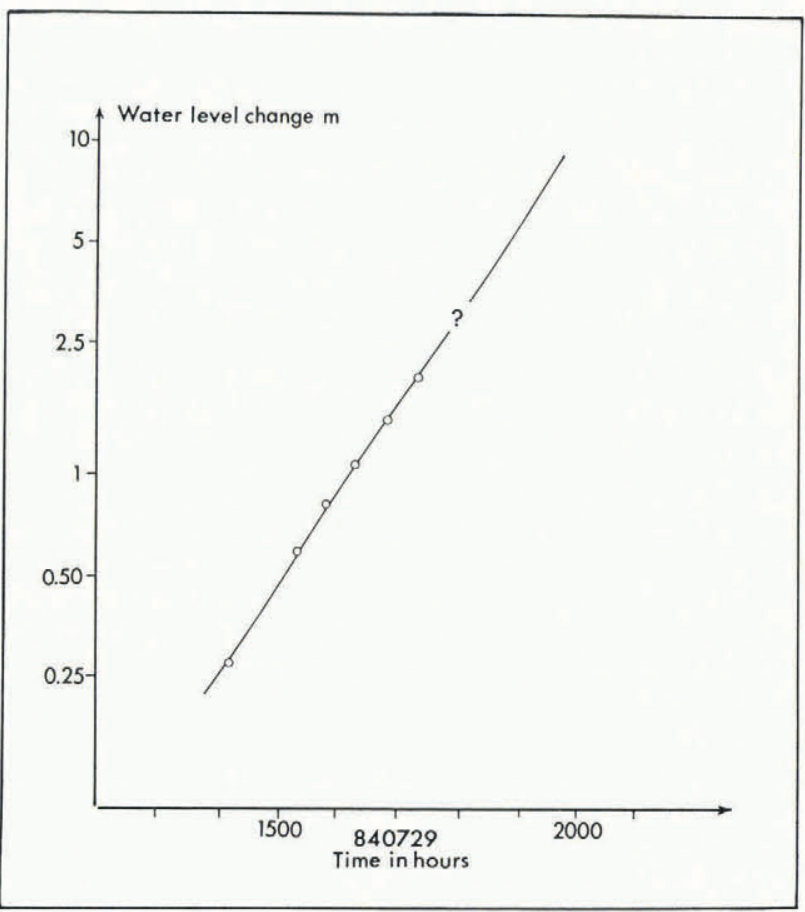

Fig. 5. Conductivity and $\delta^{18} \mathrm{O}$ values of water samples from site 2 (top) and water-level recordings from sites 1 and 2 (bottom), 23-30 July 1984.

Until 24 July, glacier-river discharge and conductivity displayed a regular daily pattern, with a single maximum and minimum. The decline of conductivity from 17 July undoubtedly reflected an increase in the contribution made to total discharge by melt water derived from the glacier's upper surface, a usual development through the ablation period (Collins and Young, 1981; Andreasen, 1985). A declining trend of $\delta^{18} \mathrm{O}$ values, which ended on $17 \mathrm{July}$, reflected the decreasing contribution made to river discharge by the melting of snow which had accumulated in the lower part of the catchment during the previous winter.

The river-level fluctuations at site 2 between 25 and 28 July suggested that the system draining to the site was blocked, or otherwise disrupted, temporarily (Fig. 5). Towards the end of this period, sudden decreases of conductivity occurred during periods of increasing discharge. Although the ${ }^{18} \mathrm{O}$ content of the glacier-river water was increasing between 22 and 26 July, diurnal fluctuations, which are characteristic of much of the ablation season, were superimposed on the trend. However, on 27 July, as

$\mu \mathrm{S} \mathrm{cm} \mathrm{cm}^{-1} \cdot 10^{-6}$

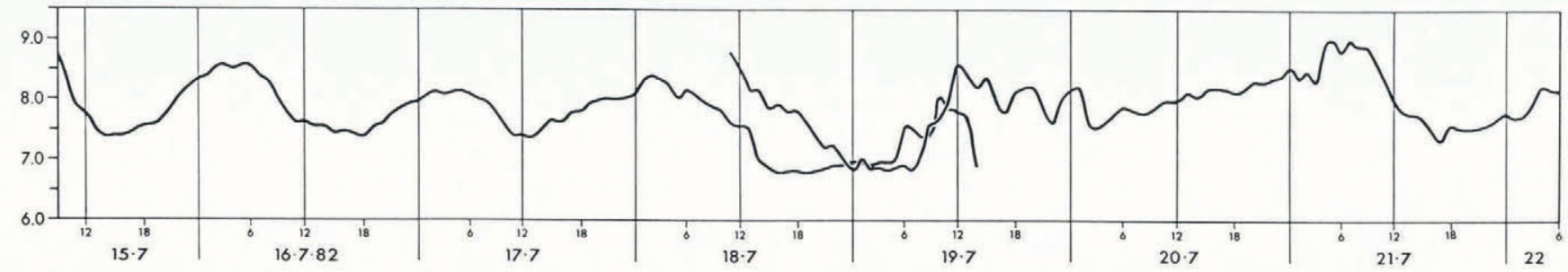

Fig. 4. Electrical conductivity of the glacier river at site 2 (15-19 July) and site I (18-22 July) in 1982. The lag of changes at site 1 behind those at site 2 reflected its greater distance from the glacier. The recorder at site 2 was put out of action by the flood of 19 July. 
TABLE II. GLACIER-RIVER LEVEL AND WATER-QUALITY VARIATIONS, AUSTRE OKSTINDBREEN, 1984

Before 25 July

25 July

26 July

27 July

28 July

29 July
Systematic, but out of phase, discharge and conductivity patterns. After a 17 July maximum, conductivity declined. $\delta^{18} \mathrm{O}$ values declined until 17 July, and then rose steadily, with superimposed diurnal fluctuations

Amplitude of discharge cycle reduced. Water level high for about $7 \mathrm{~h}$ at site 2, after an abrupt rise at $11.00 \mathrm{~h}$. Conductivity values more irregular. Diurnal cycle of $\delta^{18} \mathrm{O}$ values

Heavy rain continued from night of 25-26 July. No afternoon decline of discharge. Water level at site 2 fluctuating; an abrupt rise, followed by a fall, soon after $18.00 \mathrm{~h}$

Rainfall ceased during the morning. General pattern of water-level changes at sites 1 and 2 similar, with recession from $07.00 \mathrm{~h}$ peak but superimposed irregularities at site 2. Conductivity variable, with a sharp afternoon fall. Rapid fall of $\delta^{18} \mathrm{O}$ values to a minimum at $22.30 \mathrm{~h}$

Fine weather. Diurnal discharge cycle, but "peak" at site 1 rather flat. Continuing water-level variability at site 2 . Marked variation of $\delta^{18} \mathrm{O}$ values around a general rising trend

Lake drained. River discharge began to increase about $2 \mathrm{~h}$ before "normal" and rose steadily through the afternoon and early evening. A marked fall in conductivity to the summer's absolute low in the early afternoon; a subsequent rise (starting about $14.30 \mathrm{~h}$ ) interrupted by one sharp fall. $\delta^{18} \mathrm{O}$ values fluctuated in the morning; high values were sustained in the afternoon and evening discharge and conductivity decreased, the heavy isotope abundance fell sharply to the summer's lowest level $\left(\delta^{18} \mathrm{O}\right.$ value: $-13.65 \%$ ).

Discharge started to increase early on 29 July (at about $05.00 \mathrm{~h}$ at site 2 and at $10.00 \mathrm{~h}$ at site 1). The peak value was around $32 \mathrm{~m}^{3} \mathrm{~s}^{-1}$, compared with normal values within the range $7-15 \mathrm{~m}^{3} \mathrm{~s}^{-1}$. At both sites, the river level rose above that which the water-level recorders could accommodate, so that it is possible only to estimate the highest level. Both recorders went out of range at $17.20 \mathrm{~h}$; the one at site 2 was flooded and stopped operating, whilst that at site 1 was within range again at $21.00 \mathrm{~h}$. The fall of conductivity was very marked, the value reaching an absolute low for the summer during the hours before the lake drained and even after drainage had started. It was only when discoloration of the water at site 2 was observed, after $14.30 \mathrm{~h}$, that conductivity began to rise. Drainage of the glacier-dammed lake was marked by isotopically heavy water issuing from the glacier for some $18 \mathrm{~h}$ (Fig. 5). Sampling at half-hourly intervals between 15.20 and $17.50 \mathrm{~h}$ revealed that the ${ }^{18} \mathrm{O}$ content of the water emerging from the glacier was high (Table III). The differences of the $8^{18} \mathrm{O}$ values of samples collected during the early stage of lake drainage on 29 July at $12.20 \mathrm{~h}$

TABLE III. CATION CONCENTRATIONS (ppm) AND $\delta^{18} \mathrm{O}$ VALUES (\%) OF WATER SAMPLES AT SITE 2 BEFORE, DURING, AND AFTER DRAINAGE OF THE ICE-DAMMED LAKE IN 1984. SAMPLES FROM OTHER SOURCES, INCLUDING THE LAKE BEFORE IT DRAINED, ARE LISTED AT THE BOTTOM

\begin{tabular}{|c|c|c|c|c|c|c|}
\hline Date & Time & $\mathrm{Na}^{+}$ & $K^{+}$ & $\mathrm{Ca}^{++}$ & $\mathrm{Mg}^{++}$ & $\delta^{18} O$ \\
\hline \multirow[t]{13}{*}{29 July } & 00.20 & 0.55 & 0.12 & 0.15 & 0.08 & -13.37 \\
\hline & 02.20 & 0.56 & 0.10 & 0.16 & 0.11 & -13.31 \\
\hline & 04.20 & 0.60 & 0.11 & 0.18 & 0.11 & -13.45 \\
\hline & 06.20 & 0.58 & 0.06 & 0.18 & 0.07 & -13.29 \\
\hline & 12.20 & 0.56 & 0.10 & 0.18 & 0.07 & -13.34 \\
\hline & 14.20 & 0.52 & 0.24 & 0.21 & 0.10 & -12.99 \\
\hline & 15.20 & 0.53 & 0.39 & 0.22 & 0.14 & -12.92 \\
\hline & 15.50 & 0.55 & 0.79 & 0.22 & 0.10 & -12.92 \\
\hline & 16.20 & 0.67 & 1.02 & 0.40 & 0.27 & -12.92 \\
\hline & 16.50 & 0.62 & 2.86 & 0.57 & 0.39 & -12.67 \\
\hline & 17.20 & 0.59 & 2.79 & 0.58 & 0.59 & -12.78 \\
\hline & 17.50 & 0.60 & 3.00 & 0.57 & 0.70 & -12.76 \\
\hline & 20.20 & 0.81 & 4.50 & 0.74 & 0.97 & -12.69 \\
\hline 30 July & 15.20 & 0.58 & 0.26 & 0.24 & 0.09 & -13.16 \\
\hline \multicolumn{7}{|c|}{ Supraglacial } \\
\hline melt $w$ & & 0.00 & 0.00 & 0.01 & 0.00 & -11.75 \\
\hline Rain $w$ & & 0.15 & 0.07 & 0.05 & 0.04 & -8.66 \\
\hline \multicolumn{7}{|c|}{ Pro-glacial } \\
\hline stream & & 0.81 & 0.75 & 1.54 & 0.28 & \\
\hline \multicolumn{7}{|c|}{ Ice-dammed } \\
\hline lake & & 0.42 & 0.07 & 0.13 & 0.04 & \\
\hline
\end{tabular}


$(-13.34 \%)$ and $14.20 \mathrm{~h}(-12.99 \%)$, and during the final phase of the event on 30 July at $04.20 \mathrm{~h}(-12.67 \%)$ and $06.20 \mathrm{~h}(-13.25 \%)$ were striking.

Analyses of samples collected from the ice-dammed lake before it drained revealed that, in itself, the water was unable to cause much increase of conductivity. The concentration of $\mathrm{Na}^{+}$and $\mathrm{Ca}^{++}$was about two or three times that of rain-water samples, whilst the concentration of $\mathrm{Mg}^{++}$and $\mathrm{K}^{+}$was about the same as in rain water (Table III). Most of the lake's solute content is probably derived by contact with rock and debris surfaces.

During the lake outbursts, $\mathrm{Na}^{+}$concentrations at site 2 were very similar to those registered before the event (Table III). $\mathrm{K}^{+}$concentrations rose only slightly during the early phase of the lake outburst, but increased rapidly in the next few hours, to reach a value of about $4.5 \mathrm{ppm}$ at around the time of maximum discharge. Obviously, many $\mathrm{K}$ ions were carried with the water, possibly in connection with the high sediment content. Before the outburst, the $\mathrm{Ca}^{++}$content of the lake water was similar to that of glacier-river water: lake water cannot explain the trebling of $\mathrm{Ca}^{++}$concentrations during the outburst (Table III). $\mathrm{Mg}^{++}$ showed much the same variation as $\mathrm{Ca}^{++}$.

A visit to the glacier-dammed lake at $14.00 \mathrm{~h}$ on 29 July revealed that drainage had begun (Fig. 6). During the
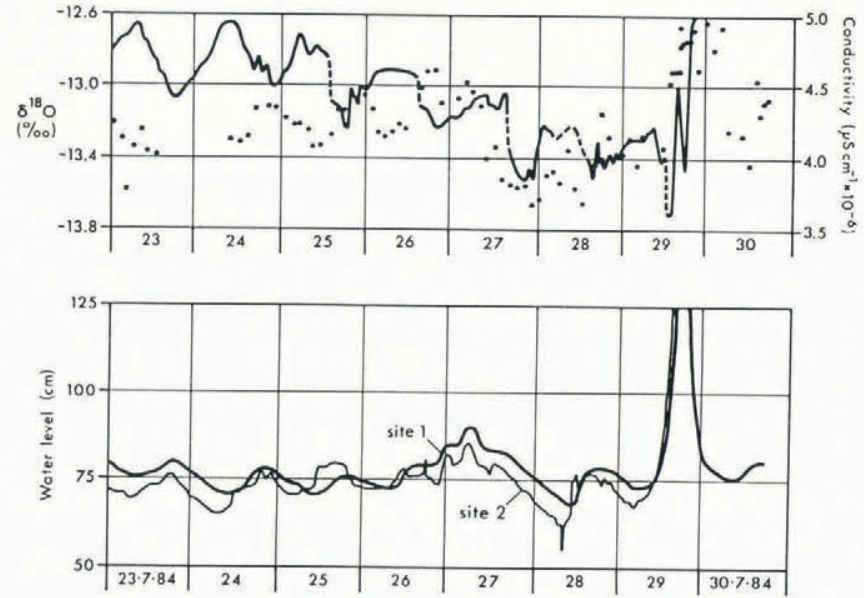

Fig. 6. At $14.00 \mathrm{~h}$ on 29 July 1984, drainage of the ice-dammed lake had begun. The maximum water level was indicated by the colour change of the glacier surface. In the background (view towards the south), the snow cover was collapsing as a result of lake drainage.

following $3 \mathrm{~h}$, the level fell continuously, the change following an exponential function (Fig. 7). Drainage was complete within $7 \mathrm{~h}$. Extensive vertical fluting was present on the steep exposed glacier margin. Between 17.00 and $17.30 \mathrm{~h}$, water forced its way up through the glacier, emerging at the surface where there was a cover of about $1 \mathrm{~m}$ of old snow; the snow was fractured into large blocks (Fig. 8). The water, strongly discoloured by the high sediment content, fountained to a height of almost $0.5 \mathrm{~m}$ above the glacier surface. From its point of emergence, it flowed along the glacier margin, some re-entering through crevasses or by flowing back beneath the ice. Some water rose to the ice surface through crevasses as far as $50 \mathrm{~m}$ from the margin, indicating that conduits were filled and that the pressure gradient was forcing water towards the surface. On a map, it is possible to draw an almost straight line along the glacier margin between the lake and the outburst site at about $830 \mathrm{~m}$ (Fig. 1).

Radiation, temperature, and wind-velocity data recorded on 28,29 , and 30 July were very similar. As there was no precipitation, the discharge caused by ablation $\left(Q_{\mathrm{a}}\right)$ on 29 July is taken as the mean of the discharge of 28 July and 30 July (Fig. 9); variations in discharge at site 1 , both during the days immediately preceding the lake outburst and those which followed it, were within the range $6.5 \pm 0.5 \mathrm{~m}^{3}$ $\mathrm{s}^{-1}$. Subtraction of $Q_{\mathrm{a}}$ from the total discharge $\left(Q_{\mathrm{t}}\right)$ yields the discharge from the ice-dammed lake $\left(Q_{j}\right)$ (Table IV).

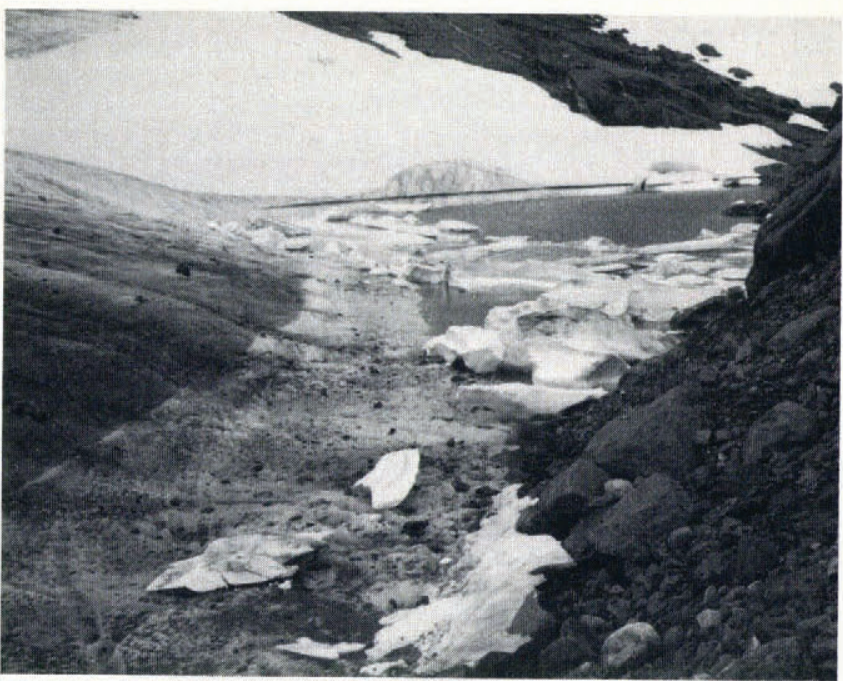

Fig. 7. The fall of water level of the ice-dammed lake on 29 July 1984 followed an exponential function. The last of the six measurements on which the line is based was made at $17.20 \mathrm{~h}$, when the lake level had been lowered by $1.94 \mathrm{~m}$.

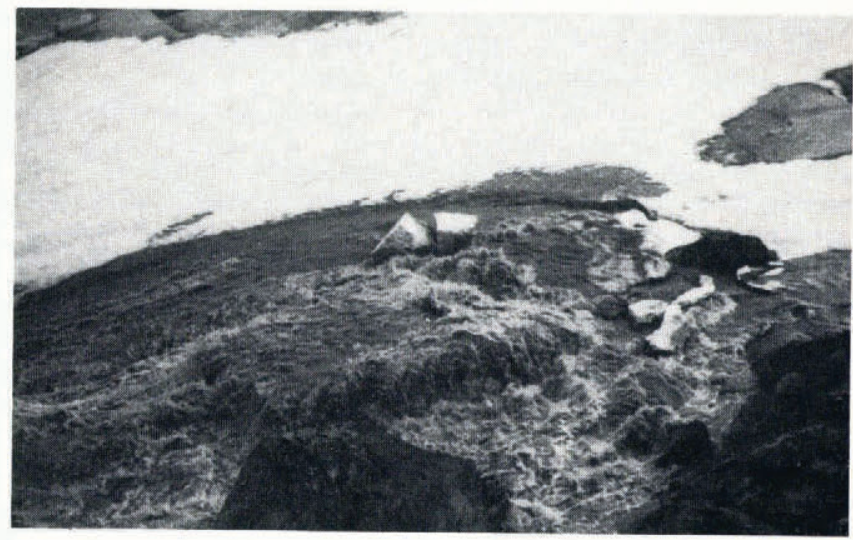

Fig. 8. As the ice-dammed lake drained on 29 July 1984 highly turbid water forced its way up through the glacier. emerging at the surface where there was a cover of about $1 \mathrm{~m}$ of snow. Subsequent inspection revealed that a subglacial tunnel extended both up-glacier and down-glacier from the site.

The calculated total volume of water draining from the lake during the outburst, $3.6 \times 10^{5} \mathrm{~m}^{3}$, is in good agreement with the value determined for the 1976 outburst (Knudsen, 1978) if errors and retreat of the glacier are taken into account.

\section{DISCUSSION OF THE 1984 EVENT}

At Austre Okstindbreen, as elsewhere, an inverse relationship between river discharge and solute concentration is indicated by electrical conductivity variations (Collins, [1978]; Humphrey and others, 1986). The conductivity of glacial melt water is determined by the relative importance of components derived from subglacial, englacial, and supraglacial sources. Usually, a daily variation is caused by the fluctuating input of water formed as ice melts on the lower glacier. The late-afternoon increases of discharge commonly are accompanied by a rise of ${ }^{18} \mathrm{O}$ content, and both discharge and $\delta^{18} \mathrm{O}$ values tend to reach a minimum during the morning. The isotopic composition of the river water reflects both its origin and its residence time within the glacier: the compositions of the components (snow melt, ice melt, rain, and ground water) which contribute to glacier-river discharge differ (Moser and Stichler, 1980). Although some fluctuations of inputs of different composition to the glacier's internal drainage system are 


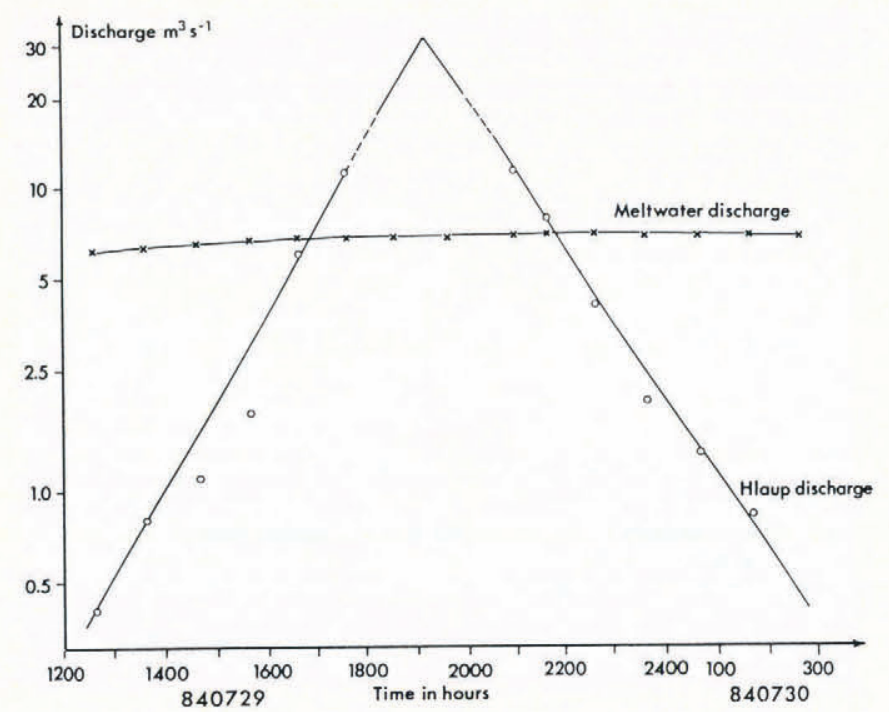

Fig. 9. The discharge of water draining from the ice-dammed lake (hlaup discharge) and the discharge of melt water from the glacier, 29-30 July 1984, plotted logarithmically with time. Melt-water discharge, based on the mean values for 28 and 31 July, varied only within the range $6.0-7.0 \mathrm{~m}^{3} \mathrm{~s}^{-1}$. The hlaup discharge between 17.20 and $21.20 \mathrm{~h}$ is estimated, as the water level was out of range; it probably reached a value of $32 \mathrm{~m}^{3} \mathrm{~s}^{-1}$.

likely to be smoothed out by the slow release of water retained in snow, firn, crevasses, and cavities, samples of glacier-river water collected at site 2 in recent summers have revealed general patterns of variation of the ${ }^{18} \mathrm{O} /{ }^{16} \mathrm{O}$ ratio, represented by the $\delta^{18} \mathrm{O}$ value (Theakstone, 1985[b]; Theakstone and Durbin, 1986).

Longer-lasting and seasonal variations of conductivity are caused by variations of water derived from melt in the accumulation area and of water draining from reservoirs in or beneath the glacier; generally, reservoir water contains more dissolved material than does water derived from the ice surface which is discharged very rapidly from the glacier (Collins, [1978]; Raiswell, 1984; Theakstone, $1985[\mathrm{a}])$.

The decline of conductivity which accompanied the decrease of discharge and of heavy-isotope abundance on the morning of 27 July cannot have resulted from dilution by ice melt water and rainfall, since both of these have relatively high $\delta^{18} \mathrm{O}$ values (Table III). The most likely

TABLE IV. TOTAL DISCHARGE $\left(\mathrm{m}^{3} \mathrm{~s}^{-1}\right)$ OF THE GLACIER RIVER $\left(Q_{t}\right)$, THAT CAUSED BY ABLATION $\left(Q_{\mathrm{a}}\right)$ AND THAT RESULTING FROM DRAINAGE OF THE ICE-DAMMED LAKE $\left(Q_{j}\right)$ ON 29-30 JULY 1984. ABLATION-GENERATED VALUES ARE BASED ON VARIATIONS RECORDED DURING THE DAYS IMMEDIATELY PRECEDING AND FOLLOWING DRAINAGE OF THE LAKE

$\begin{array}{lrrrr}\text { Date } & \text { Time } & Q_{\mathrm{a}} & Q_{j} & Q_{\mathrm{t}} \\ 29 \text { July } & 12.40 & 6.2 & 0.4 & 6.6 \\ & 13.40 & 6.3 & 0.8 & 7.1 \\ & 14.40 & 6.5 & 1.1 & 7.6 \\ & 15.40 & 6.6 & 1.8 & 8.4 \\ & 16.40 & 6.7 & 6.0 & 12.7 \\ & 17.40 & 6.7 & 11.1 & 17.8 \\ & & & & \\ & 21.00 & 6.9 & 10.9 & 17.8 \\ & 21.40 & 6.9 & 7.8 & 14.7 \\ & 22.40 & 6.9 & 4.0 & 10.9 \\ 30 \text { July } & 23.40 & 6.7 & 1.9 & 8.6 \\ & 00.40 & 6.7 & 1.3 & 7.9 \\ & 01.40 & 6.6 & 0.8 & 7.4\end{array}$

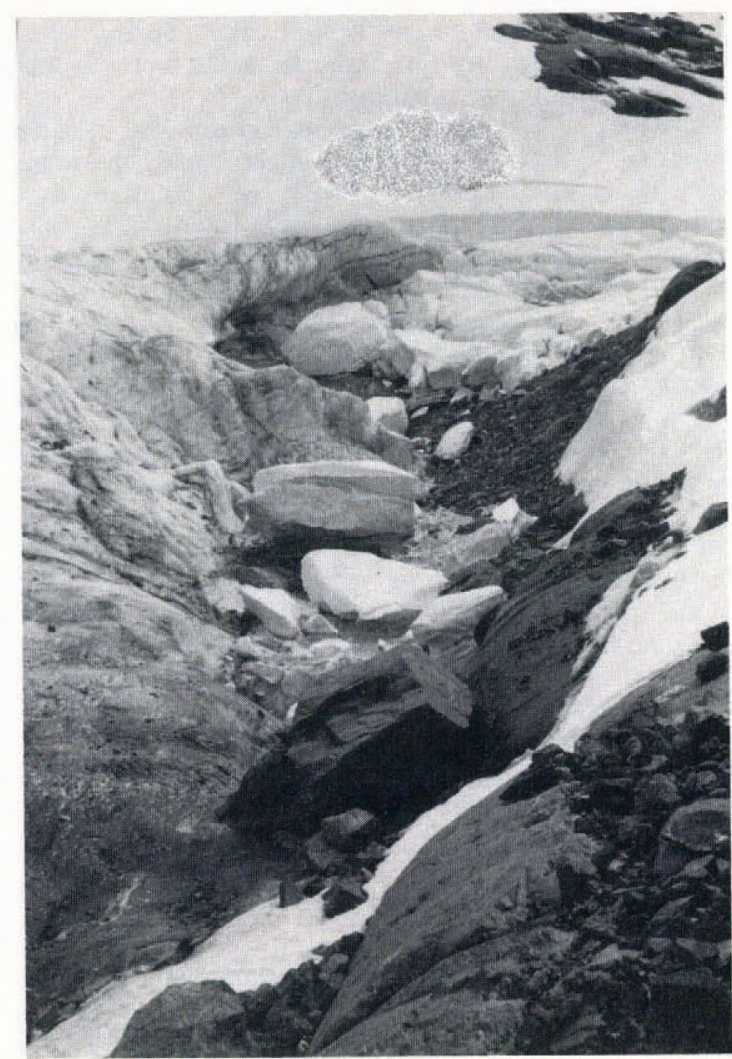

Fig. 10. Stranded snow blocks and a collapsed snow cover present in the basin on 6 July 1985 indicated that the ice-dammed lake had drained within the previous few days. View towards the south.

explanation of the change of conductivity is that, following the rainfall of the preceding days, water was being released from storage within parts of the glacier at which sources of solutes were not readily available.

Although warm, sunny weather contributed to melting of the glacier surface on 28 July, the ice melt water apparently was mixed with water depleted of heavy isotopes: $\delta^{18} \mathrm{O}$ and conductivity values of the glacier-river water varied somewhat erratically. The irregular conductivity variations recorded in the period leading up to the lake outburst indicate that the contributions of solute-rich and solute-poor water to total discharge were becoming more variable. The sudden decreases in conductivity during increasing discharge towards the end of this period suggest that either solute-rich melt water was almost instantaneously cut off or the input of solute-poor water was increased very suddenly. Water leaking from the ice-dammed lake may have contributed to the mixing responsible for the water-quality fluctuations. The lake water itself is a mixture, having received contributions from melting snow, melting ice, and rain.

The discharge increase early on 29 July was not the result of the "normal" course of glacier melting; increasing conductivity values suggest that water which had been in contact with the glacier bed was emerging, perhaps displaced by water from the lake entering the glacier's drainage system. The sharp fall in conductivity a little before mid-day apparently reflected dilution as the contribution of surface-derived melt water to discharge increased. During the afternoon, as water escaping from the lake filled the drainage-system conduits, water was forced into contact with previously isolated areas of the bed, and entrainment of sediment increased the conductivity. However, this solute-rich water was diluted by that draining through the glacier from the lake and that generated by melting at conduit walls as their cross-sections increased.

Whilst the exponential increase of river discharge as the lake drained resembled that measured during other such outbursts (e.g. Clarke, 1982), the subsequent decline at site 1 was slower than usually seen (Fig. 9), and contrasted with the situation in 1976 (Knudsen, 1978). The rising limb of 
the hydrograph reflected the increase in diameter of conduits in the ice, as the transfer of energy by friction from the flowing water caused melting of their walls (Liestøl, 1956; Mathews, 1973; Nye, 1976). In part, the unusual form of the falling limb (which decreased exponentially at about the same rate as the rising limb increased) may reflect some temporary storage of water in the lake which lies between the end of the glacier and site 1 but, since such an effect was not evident in 1976, other causes must be sought. The form of the hydrograph during the waning stages of the flood may be influenced by turbulent friction in the conduit within or beneath the glacier and by the temperature of the water entering it, which determines the amount of heat convected down the conduit (Spring and Hutter, 1981). Water temperatures were not measured at the lake before it drained in 1984, but much of the water body is likely to have been colder than the temperature of maximum water density $\left(4^{\circ} \mathrm{C}\right)$ : large snow floes were present at the surface, the surface area is large in relation to the lake's volume, and winds channelled through the gorge in Leirskardalen immediately to the west are likely to have ensured that the water was well mixed. In part, therefore, the relatively symmetrical form of the hydrograph might reflect a conduit-entrance temperature of about $2{ }^{\circ} \mathrm{C}$ during much of the outburst. High turbulence of the water within the conduit, indicated by the substantial entrainment of sediment, may have been another contributory factor: significant energy losses must have occurred during entrainment. Once water ceased to issue from the lake, water which had previously been stored within the glacier at sites outside the conduit may have played some part in determining river discharge.

\section{GENERAL DISCUSSION AND CONCLUSIONS}

Both the 1977 and 1984 outbursts of the Austre Okstindbreen lake were complete within 6-7 h, and discharge records suggest that the 1976, 1982, and 1987 events were of similar duration. Although the 1984 hydrograph diverged markedly from the classic model of many glacial-lake outburst floods (Fig. 9), the relation between the initial lake volume $\left(V_{0}\right)$ and the peak discharge $\left(Q_{\max }\right)$ fits the empirical Clague-Mathews relation $Q_{m}$ $75\left(V_{0} / 10^{6}\right)^{0.67}$ (Clague and Mathews, 1973): with $V_{0}=3.4 \times$ $10^{5} \mathrm{~m}^{3}$, this expression yields $Q_{\max }=36.5 \mathrm{~m}^{3} \mathrm{~s}^{-1}$, which is fairly close to the estimated peak of 29 July. Whilst it is to be expected that the discharge of the river as the lake drains is related to the volume of water which has left the basin, this relationship does little to explain the event.

The range of possible causes of glacier-outburst floods is wide (Röthlisberger and Lang, 1987) and the course of such events is variable: theoretical considerations do not account for the observed variety (Haeberli, 1983). The behaviour of the Austre Okstindbreen ice-dammed lake during 12 consecutive summers has included at least ten confirmed and one partial outburst. Although no single model can account for all the events, the observations made since 1976 do provide information useful in considering trigger mechanisms, the course of development of outburst floods, and the geometry of the system through which the water passes on its way from the lake.

Having emptied in the ablation season, the lake basin may not re-fill until the period of snow melt in the following year: large snow floes generally are present at the water surface in early summer, and snow on the basin sides extends below the water level. A "water line" etched partly in snow has been evident after some outbursts. On 21 May 1986, when all other lakes in the area still were ice-covered, the basin was full, but the water surface was ice-free. On 22 May 1987, a small amount of water was present in the bottom of the eastern part of the basin; the surface was frozen. Avalanching from the adjacent steep slopes prevented access for late-winter sampling.

Commonly, the lake discharges westward, i.e. away from the glacier, for several days or even weeks during the summer before draining beneath the glacier; the water depth at the glacier margin varies little during that period. This depth has been much the same since 1976. It seems that simple flotation and related cantilever effects can be ruled out as the trigger of the lake outbursts.
Direct observations after outbursts have shown that the bottom of the subglacial conduit leading from the basin consists predominantly of bedrock. Although sediment transport to, and deposition on, the glacier surface in 1977 and 1984 indicate that water leaving the lake subglacially may encounter permeable material at some points, it is unlikely that the outbursts start as a result of seepage through permeable material, a mechanism which, accompanied by channel development at the base of the glacier as increasing water temperature causes melting, may be responsible elsewhere (Röthlisberger and Lang, 1987).

Several outbursts have occurred when other water inputs to the glacier-drainage system were relatively large: in 1979, 1985, and 1986, the lake drained early in the summer whilst melting of the previous winter's snow cover was contributing substantially to river discharge. Such large inputs of water will affect the opening of basal cavities (Iken and others, 1983; Raymond and Malone, 1986); high basal water pressures and rapid sliding may disrupt or open conduits and reservoirs within the glacier. In 1982, drainage occurred during a major storm, at a time of very heavy rainfall. The 1984 event was preceded by a period of heavy rain, although this ended $2 \mathrm{~d}$ before the outburst. In 1987, the lake drained during an extended period of high air temperatures and rapid ablation. It is at such times of substantial water inputs from the surface that conduits near the seal which separates the glacier's principal drainage system from that directed to the lake are likely to become water-filled; the pressure within them may rise, thereby facilitating the establishment of a connection across the seal, as suggested by Theakstone (1978). In 1976, however, the lake drained at a time when melt-water production was slight; Knudsen (1978) suggested that low water pressure within the glacier's drainage system may have been a significant factor.

The 1984 water chemistry and isotope data suggest that, as in 1982, not only was the glacier-drainage system disrupted before the lake drained, but also water may have been leaking from the lake for some time before the event, in part displacing water stored within or beneath the glacier. Slight leakage may change to sustained out-flow as a result of an increase of water temperature or a fall of the piezometric level in the glacier (Fisher, 1973; Röthlisberger and Lang, 1987). The vertical fluting of the glacier margin exposed as the lake drained in 1984 may have been caused by currents set up as surface water was warmed to the maximum-density temperature; the resultant overturn would take warmer water to the lake bottom.

The evolution of discharge processes during a glacial-lake outburst is difficult, or even impossible, to predict without an exact knowledge of the initial geometry of the conduit through which water passes from the lake to its exit point from the glacier (Spring and Hutter, 1981). After the floods of 1977 and 1984, a conduit was traced both up-glacier and down-glacier from the sites at which highly turbid water burst upwards rather close to the margin. The water appeared to have exploited an existing major conduit which followed the margin for quite a distance at rather shallow depth. In both 1977 and 1984, a major conduit led from the deepest part of the drained basin after the event, and the fact that all the water which subsequently entered the basin flowed through the outlet without any damming indicated that the conduit was still connected with the glacier's principal drainage system. In 1987, however, the lake did not drain completely; the level of the water remaining in the basin fluctuated, resembling the situation which existed throughout the 1980 field season, when out-flow to the glacier could not always keep pace with concurrent in-flow to the basin. Clearly, different flow-routing patterns may occur beneath, or within, the glacier in different years.

Further outbursts from the Austre Okstindbreen icedammed lake are likely to occur. By monitoring discharge and water-quality characteristics at the lake and at the point of out-flow of the glacier river before and during the events, more light may be shed on their cause, including the possible role of increased water supply to the glacier's drainage systems from sources other than the lake, the influence of lake-water temperature on the course of an outburst, and the relationship, if any, between drainage of the lake and prior disruption of the glacier-drainage system. 
Data of value for calibrating models of catastrophic drainage events from glaciers may be obtained by continuing studies of water temperature, the rate of discharge throughout future outbursts, and exploration of conduits after them.

\section{ACKNOWLEDGEMENTS}

The authors are pleased to acknowledge the assistance given in the field by C. Durbin, P. Reimann, and L. Svendsen. The co-operation of Professor W. Dansgaard and N. Gundestrup of the Copenhagen University Geophysical Isotope Laboratory over a period of several years has contributed substantially to the success of the investigations undertaken at Okstindan. The authors are grateful to $R$. Nielsen and N. Scarle for cartographic work. The studies at Okstindan have been supported by travel grants from the British Council and the University of Manchester.

\section{REFERENCES}

Andreasen, J.-O. 1985. Basal sliding at the margin of the glacier Austre Okstindbre, Nordland, Norway. Arctic and Alpine Research, 15(3), 333-38.

Andreasen, J.-O., and Knudsen, N.T. 1985. Recent retreat and ice velocity at Austre Okstindbre, Norway. Zeitschrift für Gletscherkunde und Glazialgeologie, 21, 329-40.

Clague, J.J., and Mathews, W.H. 1973. The magnitude of jökulhlaups. Journal of Glaciology, 12(66), 501-04.

Clarke, G.K.C. 1982. Glacier outburst floods from "Hazard Lake", Yukon Territory, and the problem of flood magnitude prediction. Journal of Glaciology, 28(98), 3-21.

Collins, D.N. 1978. Hydrology of an Alpine glacier as indicated by the chemical composition of meltwater. Zeitschrift für Gletscherkunde und Glazialgeologie, 13(1/2), 1977, 219-38.

Collins, D.N., and Young, G.J. 1981. Meltwater hydrology and hydrochemistry in snow- and ice-covered mountain catchments. Nordic Hydrology, 12(4-5), 319-34.

Fisher, D. 1973. Subglacial leakage of Summit Lake, British Columbia, by dye determinations. International Association of Scientific Hydrology Publication 95 (Symposium at Cambridge, 1969 - Hydrology of Glaciers), 111-16.

Haeberli, W. 1983. Frequency and characteristics of glacier floods in the Swiss Alps. Annals of Glaciology, 4, $85-90$

Hoel, A. 1910. Okstinderne. Fjeldgrunden og bræerne. Norges Geologiske Undersøkelse. Aarbok, 57(II).

Hoel, A. 1962. Investigations on some glaciers in northern Norway. The glaciers of the Okstindan mountains. Norsk Polarinstitutt. Skrifter, 114, 219-52.

Humphrey, N., Raymond, C., and Harrison, W. 1986. Discharges of turbid water during mini-surges of Variegated Glacier, Alaska, U.S.A. Journal of Glaciology, 32(111), 195-207.

Iken, A., Röthlisberger. H., Flotron, A., and Haeberli, W. 1983. The uplift of Unteraargletscher at the beginning of the melt season - a consequence of water storage at the bed? Journal of Glaciology, 29(101), 28-47.

Knudsen, N.T. 1978. Drainage of an ice-dammed lake, Okstindan, Nordland, Norway. Norsk Geografisk Tidsskrifl, 32(1), 55-61.

Lewis, R. 1967. Geomorphological aspects of Austre Okstindbreen. Svartisen Expedition Report, 66.

Liestøl, O. 1955-56. Glacier dammed lakes in Norway. Norsk Geografisk Tidsskrift, 15(3-4), 122-49.

Mathews, W.H. 1973. Record of two jökulhlaups. International Association of Scientific Hydrology Publication 95 (Symposium at Cambridge 1969 Hydrology of Glaciers), 99-110.

Moser, H., and Stichler, W. 1980. Environmental isotopes in ice and snow. In Fritz, P., and Fontes, J. C., eds. Handbook of environmental isotope geochemistry. Amsterdam, etc., Elsevier Scientific Publishing Company, $141-78$.

Nye, J.F. 1976. Water flow in glaciers: jökulhlaups, tunnels and veins. Journal of Glaciology, 17(76), 181-207.

Raiswell, R. 1984. Chemical models of solute acquisition in glacial melt waters. Journal of Glaciology, 30(104), 49-57.

Raymond, C.F., and Malone, S. 1986. Propagating strain anomalies during mini-surges of Variegated Glacier, Alaska, U.S.A. Journal of Glaciology, 32(111), 178-91.

Röthlisberger, H., and Lang, H. 1987. Glacial hydrology. In Gurnell, A.M., and Clark, M.J., eds. Glaciofluvial sediment transfer: an alpine perspective. Chichester, John Wiley and Sons, 207-84.

Spring, U., and Hutter, K. 1981. Numerical studies of jökulhlaups. Cold Regions Science and Technology, 4(3), 227-44.

Theakstone, W.H. 1978. The 1977 drainage of the Austre Okstindbreen ice-dammed lake, its cause and consequences. Norsk Geografisk Tidsskrift, 32(4), 159-71.

Theakstone, W.H. 1985[a]. Aspects of glaciers and their beds. In Pitty, A., ed. Themes in geomorphology. London, etc., Croom Helm Publishing Company, 1-17.

Theakstone, W.H. 1985[b]. The drainage of the Austre Okstindbreen glacier-dammed lake. In Rose, J., and Whiteman, C.A., eds. Okstindan Research Project. Preliminary report for 1983. London. University of London. Birkbeck College. Department of Geography, 49-62.

Theakstone, W.H., and Durbin, C.S. 1986. Oxygen isotope variations in glacier river water, Austre Okstindbreen, Okstindan, Norway. Okstindan Glacier Project. Report, 86.1 .

Theakstone, W.H., and Knudsen, N.T. 1981. Dye tracer tests of water movement at the glacier Austre Okstindbreen, Norway. Norsk Geografisk Tidsskrift, 35(1), 21-28.

Worsley, P. 1974. Recent "annual" moraine ridges at Austre Okstindbreen, Okstindan, north Norway. Journal of Glaciology, 13(68), 265-77. 